\title{
A Therapeutic Communication Study of Families with Children Suffering from Cancer
}

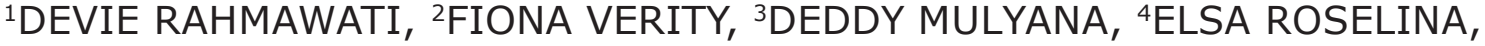 \\ ${ }^{5}$ WIRATRI ANINDHITA
}

\begin{abstract}
${ }^{1}$ Vocational Program, University of Indonesia, Kukusan Beji Kota Depok, ${ }^{2}$ Human and Health Sciences College, Swansea University, UK, Singleton Park, Swansea, Wales SA2 8PP, ${ }^{3}$ Faculty of Communication Science,Padjadjaran University, Jl. Raya Bandung Sumedang Km 21 Jatinangor, ${ }^{4}$ Vocational Program, University of Indonesia, Kukusan Beji Kota Depok ${ }^{5}$ Communication Department, Kwik Kian Gie School of Business, Jl. Yos Sudarso Kav 87, Sunter Jakarta

email: ${ }^{1}$ deviers@vokasi.ui.ac.id ${ }^{2}$ f.e.verity@swansea.ac.uk ${ }^{3}$ deddy.mulyana@unpad.ac.id ${ }^{4}$ elsa@vokasi.ui.ac.
\end{abstract} id ${ }^{5}$ dhita@kwikkiangie.ac.id

\begin{abstract}
Therapeutic communication is a relatively new area of research in Indonesia. It is widely known that the success of therapeutic communication is largely influenced by the medical providers' communication effectiveness when dealing with their clients. This study aimed to explore the connection between therapeutic communication and satisfaction or dissatisfaction as experienced by families of children suffering from cancer. It used a quantitative approach with a cross-sectional design. The research samples were families of children suffering from cancer who accompanying the patients during hospital stay treatment at one of Indonesian public hospitals in Jakarta over the period of December 2014 to March 2015. There were 23 respondents for this research. The statistical test used was chi-square with an 0.05 level of significance. The result indicated that $56.5 \%$ of the respondents were satisfied with the therapeutic communication provided by nursing staff and those who practiced good therapeutic communication. A good therapeutic communication were 22 times more likely to provide a satisfactory level to the families of child with cancer compared with those who did not apply good therapeutic communication (the value of $p=0.003$ and Odds ratio $=22$ ). The research indicated that the effective communication from medical providers was associated with the patients' satisfaction. It suggests that medical providers should be involved in workshops on how to improve their communication skills to make their clients more satisfied with the medical services.
\end{abstract}

Keywords: therapeutic communication, family satisfaction, cancer

\section{Introduction}

Almost a million of Indonesians travel overseas annually, notably Singapore and Malaysia, to get medical treatment (Mulyana $\&$ Verity, 2016:309). One of possible reasons is that healthcare providers, especially physicians, are not friendly enough to communicate with patients and their families. They seem to practice what Charles et al. (2004) call the paternalistic model of doctor-patient communication in which information flows one way from doctors to patients without giving sufficient time to and encouraging patients to ask necessary questions about their ailments. Meanwhile, according to the Ministry of Tourism (2013), the reason for so many Indonesian citizens going abroad for medical treatment, among others, is to seek more sophisticated medical technology, superior medical services, a relatively cheaper medical treatment services, and better nursing services.

For many patients and their families in Indonesia, satisfaction of therapeutic communication as employed by medical/ healthcare providers is so important that they do not mind to get better medical services overseas even if they have to spend more money. It is assumed that the medical staff's effective therapeutic communication is closely connected with satisfaction as felt by patients and their families. Thus, this study attempts to find out how effective therapeutic communication employed by the medical staff

Received: July 16, 2017, Revision: Oktober 15, 2017, Accepted: December 13, 2017

Print ISSN: 0215-8175; Online ISSN: 2303-2499. DOI: http://dx.doi.org/10.29313/mimbar.v33i2.2849.439-446

Accredited B based on the decree No.040/P/2014, valid on February, 18, 2014 until February, 18, 2019. Indexed by DOAJ, Sinta, IPI 
in a public hospital in Jakarta is associated with satisfaction felt by families who have children suffering from cancer.

Hugman (2009:16) suggests that effective communication means that "both (or all) parties feel that mutual needs have been met (both utilitarian and emotional) and that an agreed goal of some kind has been achieved as far as possible." Similarly Eggly et al. (2009:66) argue that effective communication is related to positive outcomes for one or more of the participants, that is, patients, family members, clinicians, institutions, society, or all of these. According to Berry (2007:3), "Effective communication is now generally acknowledged to be central to effective healthcare. It is no longer seen as an add-on extra; rather it is recognized by many as being at the heart of patient care as playing a pivotal role."

In the context of child suffering from cancer, the effect of communication with the parents is positively correlated with the effect of communication with the child patients (Koerber, 2012). Consequently, the medical staff's effective communication with a patient's parents is imperative to ensure that the child suffering from cancer obtains the best medical treatment. Yet it is established that families with children suffering from cancer have various problems that adversely affect their health care and recovery, including poor communication with physicians, lack of knowledge about cancer, and their management, financial, emotional, psychological, and health insurance problems (Monterosso \& Kristjanson, 2008; Jerant et al., 2005; Mallinger et al., 2005; Skalla et al., 2004).

Although Indonesia has hundreds of universities offering academic programs in communication, healthcare, and medicine, and despite the fact that Indonesia has a population of over 250 million, studies of health communication and more specifically of therapeutic communication are still scarce either based on the interpretive/constructivist paradigm or the objective/empirical paradigm.

Since Indonesia consists of hundreds of ethnic groups with different cultural beliefs and values, in addition to a great number of subcultural groups, studies of therapeutic communication in Indonesia based on the interpretive paradigm and the social construction theory are more appealing. Members of those ethnic groups and subcultural groups may define illness differently, referring to different socialcultural causes that have to be overcome by different social-cultural solutions. Of such studies, Hadisiwi (2011) explored the meaning of Filariasis as constructed by those who suffered from such illness in Bandung Regency, while Hafiar (2012) explored the phenomenological experiences of disabled athletes in Bandung. Slightly different from those two studies, Mulyana and Sulaeman (2016) developed a typology of Oligodactyly sufferers, meaning construction and themes related to their communication experiences. The research subjects considered their suffering of Oligodactyly in terms of having a different body, a body cursed by God, and the body as God's bounty. The subjects were abandoned and discriminated by their immediate families as well as people outside their families.

Examining online game addiction considered to be a sort of psychological illness. Most recently based on interpretiveinductive study, Rahmawati (2017) found three categories of online game players in the internet café: zombie character, crowd, and champion. She contrasted the three types of players in terms of the communication competence and communication patterns with their significant others. This study argues that many claims about online game addiction are not accurate and the criteria of addiction based on studies conducted in Western countries are not true. This research found that online game players still have ethical norms like other people.

Based on the objective-quantitative perspective, there have been a smaller number of studies on how health communication and therapeutic communication in particular by health professionals affect patient attitudes and satisfaction. For instance, Iba (2005) examined the correlation between paramedic communication and the patient attitudes towards the medical service in a public hospital in the Southeast Sulawesi, while Dida (2011) examined the effect of the optimization of health communication on the enhancement of children's health in a health service center in West Java. Some studies have dealt with the effect of certain social (communication) strategies on patient health. Among others, Hatta (2013) examined the effect of group counseling on the self-regulation of drug (ecstasy) users with the results that the group counseling contributed to the self-regulation of the ecstasy users. Yusuf and Setianto (2013) examined the effect of 'Cognitive 
Behavior Therapy' on the decrease of stress intensity among patients suffering from Low Back Pain (LBP) in ' $X$ ' Hospital in Bandung. They found that the Cognitive Behavior Therapy decreased the degree of the stress among the LBP patients.

In this context, our study is intended to fill in the scarcity of research on communication between medical providers and patient. Although this study tries to find out the satisfaction of therapeutic communication as felt by families whose children suffer from cancer, it may lead to further studies that involve other families whose members suffer from other ailments, such as tuberculosis, heart attack, psychological disturbance, and general diseases.

The purpose of this study is to investigate whether there is a connection between therapeutic communication employed by the medical staff (nurses) and the satisfaction of cancer patients' families. It also aims to explore aspects of dissatisfaction with therapeutic communication as employed by the medical staff. It is expected that the findings of this research will give some feedback to the medical staff to improve their services for children suffering from cancer as well as their families.

\section{Methodology}

This research employed a quantitative research method using a cross-sectional survey design. The SPSS Version 16.0 was used to analyze the data. The statistical test used was chi-square with a 0.05 level of significance. The questionnaire asked a series of questions about communication relationships in a hospital environment using a modified version of Fatriansari's (2012) tested tool. These were completed by the patient's family members. It took the researchers one week to collect the results of the questionnaires. This was due to the 'emotional roller coaster' (Robinson \& Watson, 2005) being experienced by families of children with cancer patients. Only after having intensive interpersonal communication with the researchers they are willing to complete the questionnaires and even then, only when facilitated with assistance from the researchers.

The questions investigated in this research are; a) exploring the satisfaction of families who had children suffering from cancer, with the performance of therapeutic communication of health staff; and b) gaining insights into aspects of dissatisfaction with therapeutic communication and barriers when communicating with health staff (nurses). The research total sample $(\mathrm{N})$ was 23 families who had children undergoing treatment in a public hospital in Jakarta in the period December 2014 to March 2015. The patients themselves were those who occupied the beds in the hospital at the time of the study. The majority of the respondents were mothers (though at times they included fathers), grandmothers, and even aunt. The median age was 33 years as it can be seen in Tables 1 and 2 below. Ethics approval was obtained by the Health Research Ethics Committee of the participating hospital. All the respondents gave informed consent to participate in the research.

Table 1

Distribution of Respondents according to Age $(\mathbf{N}=23)$

\begin{tabular}{cccccc}
\hline Variable & Mean & Median & SD & Min & Max \\
\hline Age & 35,04 & 33,00 & 9,79 & 19,00 & 54,00 \\
\hline
\end{tabular}

Source: Research Results

Table 2

Characteristics of Respondents by Gender and Occupation $(\mathbf{N}=\mathbf{2 3})$

\begin{tabular}{lcc}
\hline \multicolumn{1}{c}{ Variable } & Total & Percentage \\
\hline Gender & & \\
Male & 3 & 13,0 \\
Female & 20 & 87,0 \\
$\begin{array}{l}\text { Occupation } \\
\text { Public Service/State }\end{array}$ & 1 & 4,3 \\
Owned Industry & & \\
Private sector worker & 1 & 4,3 \\
Self-employed & 1 & 4,3 \\
Housewives & 17 & 79,3 \\
Laborers & 3 & 13 \\
\hline
\end{tabular}

Source: Research Results

\section{Research Findings}

It was found that in general, nurses engaged in therapeutic communication techniques when providing service to child patients and their families. Table 3 shows that $56,5 \%$ of the survey respondents considered that the communication by nurses was already good and were satisfied with nurse's communication. 
However, in the communication with nurses there were some emotional and informational areas which respondents did not view as satisfactory. In respect to emotional characteristics, those areas viewed as less than satisfactory were: asking every day about how the child was feeling; giving encouragement so that the child did not give up hope during treatment; listening carefully when being informed of complaints, and reacting patiently when being informed of complaints. In respect to informational communication, those areas viewed as less than satisfactory were providing clear information about reasons and goals of certain actions and effects of certain actions; providing heartfelt praise when family members do things which help towards patient's recovery; friendliness; the use of understandable language; providing opportunities for families to make decisions; respect for family decisions with regard to medicinal treatment and coordination with medical staff regarding their child's treatment.

There were a number of respondents who felt that essential components of therapeutic communication were only 'sometimes performed' by the nurses towards the patients and their families as follows: a) Spoken Greetings: (5 respondents $(21,7 \%$ ) felt that the nurses sometimes spoke greetings to the family or patient, b) Calling the child by name during treatment $(8,7 \%$ of the 23 respondents), c) Using a friendly tone when making communication $(4,3 \%$ of the 23 respondents), d) Listening with full attention $(8,7 \%$ of the 23 respondents), e) Explaining their actions (13,0\% of the 23 respondents), f) Explaining the target of their actions $(4,3 \%$ of the 23 respondents), g) Explaining the effect of their actions (30,4\% of the 23 respondents).

Furthermore, there were components of the therapeutic communication that were seen as never performed by the nurses towards the patients or their families. These are listed as follows: a) Giving the opportunity to families to ask $(4,3 \%$ of the 23 participants), b)
Informing the family of the developments in the condition of their child's health $(13 \%$, with the excuse that the doctor would inform them), c) Providing clarification (4,3\% of the 23 participants), d) Providing an opportunity for the family to state their opinion in connection with their child's treatment (13\% of the 23 participants), e) Not forcing their own opinions ( $4,3 \%$ of the 23 participants), f) Allowing the family time to decide about continuing their child's treatment (13\% of the 23 participants). The results of this analysis are presented in full in Table 4.

Table 5 above shows the nuances of the respondents' satisfaction with the communication techniques used by the nurses.

The next stage was the process of recoding which was done by using a cut off point at the median score from the total of the therapeutic communication technique and family. Following this a process of scoring took place regarding the peformance of therapeutic communication and family satisfaction which can be seen in Table 6 . There is a strong connection between the performance of therapeutic communication and family satisfaction. A nurse who performed a good therapeutic communication has 22 times better chance of achieving family satisfaction compared to a nurse who provides less therapeutic communication, where the value of $\mathrm{p}=0.003$ and Odds Ratio $=22$.

The results of this analysis are shown in Table 7.

\section{Discussion}

As Mulyana (2016:30) suggests, medical doctors, nurses, and patients can be considered as separate groups of people, each of which has its unique cultural values that influence its members to communicate verbally and nonverbally with others. The problems will become more complicated if they come from different social, ethnic, racial, or religious backgrounds with different languages, worldviews, beliefs, and values.

Table 3

Distribution of Respondents in according to Nurse Therapeutic Communication Application

\begin{tabular}{lcc}
\hline Application of Nurses' Therapeutic Communication Application & Total & Percentage \\
\hline Not bad & 10 & 43,5 \\
Good & 13 & 56,5 \\
\hline Total & 23 & 100,0 \\
\hline
\end{tabular}


Table 4

Survey Results: Therapeutic Communication Techniques: Level of Performance

\begin{tabular}{|c|c|c|c|c|c|c|c|c|}
\hline \multirow{3}{*}{$\begin{array}{l}\text { Therapeutic Communication } \\
\text { Techniques }\end{array}$} & \multicolumn{8}{|c|}{ Level of Performance } \\
\hline & \multicolumn{2}{|c|}{ Never } & \multicolumn{2}{|c|}{ Sometimes } & \multicolumn{2}{|c|}{ Frequent } & \multicolumn{2}{|c|}{ Always } \\
\hline & $\mathbf{n}$ & $\%$ & $\mathbf{n}$ & $\%$ & $\mathbf{n}$ & $\%$ & $\mathbf{n}$ & $\%$ \\
\hline Greetings & & & 5 & 21,7 & 8 & 34,8 & 10 & 43,5 \\
\hline Calling the child's name & & & 2 & 8,7 & 5 & 21,7 & 16 & 69,6 \\
\hline Using a friendly tone & & & 1 & 4,3 & 7 & 30,4 & 15 & 65,2 \\
\hline Listening with full attention & & & 2 & 8,7 & 10 & 43,5 & 11 & 47,8 \\
\hline Explaining their actions & & & 3 & 13,0 & 11 & 47,8 & 9 & 39,1 \\
\hline Explaining the target of their actions & & & 1 & 4,3 & 3 & 13,0 & 9 & 39,1 \\
\hline Explaining the effect of their actions & & & 7 & 30,4 & 8 & 34,8 & 8 & 34,8 \\
\hline $\begin{array}{l}\text { Giving the opportunity to families to } \\
\text { ask }\end{array}$ & 1 & 4,3 & 9 & 39,1 & 9 & 39,1 & 4 & 17,4 \\
\hline $\begin{array}{l}\text { Informing the family of the } \\
\text { developments in the condition of their } \\
\text { childs health }\end{array}$ & 3 & 13,0 & 1 & 13,0 & 9 & 39,1 & 8 & 34,8 \\
\hline Providing clarification & 1 & 4,3 & 6 & 26,1 & 10 & 43,5 & 6 & 26,1 \\
\hline $\begin{array}{l}\text { Providing an opportunity for the family } \\
\text { to state their opinion in connection with } \\
\text { their child's treatment }\end{array}$ & 3 & 13,0 & 4 & 17,4 & 11 & 47,8 & 5 & 21,7 \\
\hline Not forcing their own opinions & 1 & 4,3 & 1 & 4,3 & 13 & 56,5 & 8 & 34,8 \\
\hline $\begin{array}{l}\text { Allowing the family time to decide } \\
\text { about continuing their childs treatment }\end{array}$ & 3 & 13,0 & 1 & 4,3 & 11 & 47,8 & 8 & 34,8 \\
\hline
\end{tabular}

Source: Research Results

Table 5

Distribution of Respondents according to Family Satisfaction based on Communication Techniques $(\mathbf{N}=\mathbf{2 3})$

\begin{tabular}{|c|c|c|c|c|c|c|c|c|}
\hline \multirow{3}{*}{ Communication Techniques } & \multicolumn{8}{|c|}{ Level of Performance } \\
\hline & \multicolumn{2}{|c|}{ Dissatisfied } & \multicolumn{2}{|c|}{$\begin{array}{l}\text { Less than } \\
\text { Satisfied }\end{array}$} & \multicolumn{2}{|c|}{ Satisfied } & \multicolumn{2}{|c|}{$\begin{array}{c}\text { Very } \\
\text { Satisfied }\end{array}$} \\
\hline & $\mathrm{n}$ & $\%$ & $\mathrm{n}$ & $\%$ & $\mathrm{n}$ & $\%$ & $\mathrm{n}$ & $\%$ \\
\hline Friendly & & & 1 & 4,3 & 20 & 87,0 & 2 & 8,7 \\
\hline Understand able language & & & 1 & 4,3 & 18 & 78,3 & 4 & 17,4 \\
\hline Asked about child's progress everyday & & & 1 & 4,3 & 16 & 69,6 & 6 & 26,1 \\
\hline Asked how the child was feeling & & & 3 & 13,0 & 15 & 65,2 & 5 & 21,7 \\
\hline Listened with full attention to complaints & & & 1 & 4,3 & 17 & 73,9 & 5 & 21,7 \\
\hline Responded patiently to complaints & & & 1 & 4,3 & 16 & 69,6 & 6 & 26,1 \\
\hline $\begin{array}{l}\text { Gave encouragement so that hope was not } \\
\text { lost during treatment }\end{array}$ & 1 & 4,3 & 3 & 13,0 & 16 & 69,6 & 3 & 13,0 \\
\hline $\begin{array}{l}\text { Gave clear information about reason and aim } \\
\text { of teatment }\end{array}$ & & & 1 & 4,3 & 15 & 65,2 & 7 & 30,4 \\
\hline $\begin{array}{l}\text { Gave clear information about results/side } \\
\text { effect softreatment }\end{array}$ & & & 4 & 17,4 & 18 & 78,3 & 1 & 4,3 \\
\hline $\begin{array}{l}\text { Remind a child politely when he/she didn't } \\
\text { obey rules }\end{array}$ & & & & & 21 & 91,3 & 2 & 8,7 \\
\hline $\begin{array}{l}\text { Provide honest praise when families do } \\
\text { something to help a child's recovery }\end{array}$ & & & 2 & 8,7 & 19 & 82,6 & 2 & 8,7 \\
\hline Involve the family intreatment & & & 2 & 8,7 & 17 & 73,9 & 4 & 17,4 \\
\hline Involve family in decision making & & & 2 & 8,7 & 18 & 78,3 & 3 & 13,0 \\
\hline Respect family decisions regarding medication & & & 2 & 8,7 & 18 & 78,3 & 3 & 13,0 \\
\hline $\begin{array}{l}\text { Collaborate with medical team regarding } \\
\text { patient medication }\end{array}$ & 1 & 4,3 & 1 & 4,3 & 14 & 60,9 & 7 & 30,4 \\
\hline
\end{tabular}

Source: Research Results 
Table 6

\section{Distribution of Respondents according to Family Satisfaction Performance} of Therapeutic Communication $(\mathbf{N}=23)$

\begin{tabular}{lccc}
\hline \multicolumn{1}{c}{ Variable } & N & Percentage \\
\hline Family Satisfaction & & \\
Less than satisfied (score $<45)$ & 10 & 43,5 \\
Satisfied (score $\geq 45)$ & 13 & 56,5 \\
Performance of Therapeutic Communication & & \\
Low performance $($ score $<41)$ & 10 & 43,5 \\
Good performance(score $\geq 41)$ & 13 & 56,5 \\
\hline
\end{tabular}

Source: Research Results

Table 7

Results of Bivariate Analysis of Family Satisfaction with Therapeutic Communication $(\mathbf{N}=\mathbf{2 3})$

\begin{tabular}{|c|c|c|c|c|c|c|c|c|}
\hline \multirow{3}{*}{$\begin{array}{c}\text { Performance of Therapeutic } \\
\text { Communication }\end{array}$} & \multicolumn{4}{|c|}{ Family Satisfaction } & \multirow{2}{*}{\multicolumn{2}{|c|}{ Total }} & \multirow{3}{*}{$\begin{array}{l}\text { Odds } \\
\text { Ratio }\end{array}$} & \multirow{3}{*}{ P Value } \\
\hline & \multicolumn{2}{|c|}{$\begin{array}{l}\text { Less than } \\
\text { Satisfied }\end{array}$} & \multicolumn{2}{|c|}{ Satisfied } & & & & \\
\hline & $\mathrm{n}$ & $\%$ & $\mathrm{n}$ & $\%$ & $\mathrm{~N}$ & $\%$ & & \\
\hline Low & 8 & $\begin{array}{l}80,0 \\
154\end{array}$ & 2 & 20,0 & 10 & 100,0 & 22 & 0,003 \\
\hline Total & 10 & $\begin{array}{l}10,4 \\
43,5\end{array}$ & $\begin{array}{l}11 \\
13\end{array}$ & $\begin{array}{l}04,0 \\
56,5\end{array}$ & $\frac{15}{23}$ & 100,0 & & \\
\hline
\end{tabular}

Source: Research Results

Therapeutic communication is a matter of trust; it relies heavily on the ability of the medical staff to communicate effectively with the patient. Research shows that when healthcare providers listen to patients, there is more compliance with medical regimens, patient satisfaction is increased, and physicians are less vulnerable to malpractice lawsuits (Davis et al., 2008: 168). According to Jacobalis and associates (1990), communication is the most important factor that influences satisfaction perception of hospitals by patients.

In the light of the arguments above, the findings of the research showed that the patients' families experienced satisfaction from the therapeutic communication with health staff even though there were areas of communication that seen as less than satisfactory, and thus should be improved by the medical staff. The satisfaction experienced by patients and their families can be related to a range of factors, be it interpersonal, technical, religious, and cultural. Further research on how these other factors affect the satisfaction of the patients and their families are worth doing in the future.

As Indonesians are people who believe in religion, religious beliefs were important in mediating how patients felt about expressing their views on the services and the form of non-therapeutic communication. Bartz (1986) in particular contends that personal resources, such as religious beliefs, can enable a patient to overcome uncomfortable and critical situations. The medical staff's encouragement is seen as necessary in the critical situation, for instance that the family of the patient should be calm and pray to God a lot while the medical staff serves them the best they can.

The research also showed that the information provided for families by medical and nursing staff was not sufficient. This situation indicated that to some extent the medical staff still employed paternalistic model of therapeutic communication. They give only a little chance to patients and/ or their families to discuss the nature of the ailment the patient suffer from, its consequences, and the best way to cure it.

\section{Conclusions}

It can be concluded that this research, using families of children with cancer as respondents, was generally shown that therapeutic communication by medical staff (nurses) was well employed, and this effective therapeutic communication is connected with the satisfaction of the majority of patients' 
families.

This study has focused on the individual and social aspects of therapeutic communication. There are other technical, structural and even cultural aspects of therapeutic communication that can be further investigated in the future, some of which can be explored by alternative theoretical perspectives and research methods such as phenomenology, symbolic interactionism, and ethnography that will make the research more challenging, as it may take more time to collect rich qualitative data. Based on the objective-positivist perspective, research involving a much larger sample will also be beneficial to make some generalizations that may be applied by the healthcare providers to better serve patients and their families in the real world. More specific studies comparing different groups of medical providers such as general practitioners, medical specialists, and nurses in terms of their therapeutic communication effectiveness are also worth investigating.

In the meantime, workshops should be given to both medical doctors and nurses to enhance their communication skills to deal with patients and their families, so that they can understand that the satisfaction of patients and their families depend not only on their medical expertise but also on their quality of communication with the clients.

\section{References}

Bartz, C. C. (1986). Nurse-patient Communication during Critical Illness Events (Order No. 8623822). Available from ProQuest Dissertations \& Theses Global. (303476710). Retrieved from http://search.proquest.com/docview/30 3476710 ? accountid $=17242$

Berry, D.C. (2007). Health Communication: Theory and Practice. Maidenhead, Berkshire, UK: Open University Press.

Charles, C., Amiram, G. \& Whelan, T. (2004). "Decision Making in the PhysicianPatient Encounter: Revisiting the Shared Treatment Decision-Making Model." In Michael Bury \& Jonathan Gabe, eds. The Sociology of Health and Illness: A Reader. London: Routledge.

Davis, J., Foley, A., Crigger, N., \& Brannigan, M.C. (2008). "Healthcare and Listening: A Relationship for Caring." The International Journal of Listening 22: 168-175.

Dida, S. (2011). Pengaruh Optimalisasi
Komunikasi Kesehatan pada Pusat Pelayanan Kesehatan Dasar terhadap Peningkatan Derajat Kesehatan Anak Usia Dini. Unpublished Doctoral Disssertation Padjadjaran University.

Hadisiwi, P. (2011). Konstruksi Makna Penyandang Filariasis: Studi Fenomenologi tentang Konstruksi Makna Penyandang Filariasis dalam Komunikasi Risiko Kesehatan di Kabupaten Bandung. Unpublished Doctoral Dissertation Padjadjaran University.

Hafiar, H. (2012). Cacat dan Prestasi Melalui Pengalaman Komunikasi Atlet Penyandang Cacat: Studi Fenomenologi Mengenai Konstruksi Makna Kecacatan dan Status sebagai Atlet Berprestasi Melalui Pengalaman Komunikasi Atlet Penyandang Cacat Berprestasi di Bandung. Unpublished Doctoral Dissertation Padjadjaran University.

Eggly, S., Abrecht, T.L, Kelly, K., Prigerson,, H.G. Sheldon, L.K., \& Studts, J. (2009). "The Role of the Clinician in Cancer Clinical Communication." Journal of Health Communication 14:66-75.

Fatriansari, A. (2012). Therapeutic Communication Relationships of Child Nurses and Family Satisfaction Levels with Children under Hospitalization at Al-Ihsan General Hospital of West Java Province. Depok: Unpublished Thesis, Faculty of Nursing - University of Indonesia.

Hatta, M.I. (2013). "Pengaruh 'Group Counselling' terhadap 'Self-Regulation" Pecandu Napza pada Jurnalis Televisi X." Mimbar 29 (1): 57-68)

Hugman, B. (2009). Healthcare Communication. Grayslake, IL.: Pharmaceutical Press.

Iba, L. (2005). Hubungan antara Komunikasi dari Paramedis dengan Sikap Pasien Rawat Inap Mengenai Layanan Perawatan: Studi pada Layanan Perawatan Medis Rumah Sakit Umum Daerah Propinsi (RSUP) Sulawesi Tenggara. Unpublished Master's Thesis Padjadjaran University.

Jacobalis, S. (1990). Menjaga Mutu Pelayanan Rumah Sakit. Jakarta: CitraWinduSatria.

Jerant, A.F., M.M.vonFriederichsFitzwater, andM. Moore (2005). "Patients' perceived barriers to active selfmanagemen to chronic conditions." Patient Education and Counseling 57(3): 300-7.

Koerber, C. (2012). Family Communication Practices about Death in the Setting of Pediatric malignancy relapse: A qualitative study (Order No. 3539823). Available from ProQuest Dissertations \& Theses 
Global. (1101238697). Retrieved from http://search.proquest.com/docview/11 01238697 ? accountid $=17242$.

Mallinger, J.B.,J.J.Griggs,C.G.Shields. (2005). "Patient-centered Care and Breast Cancer Survivors' Satisfaction with Information."Patient Education and Counseling 57(3):342-9.

Monterosso, L., \& Kristjanson, L. J. (2008). "Supportive and Palliative Care Needs of Families of Children who Die from Cancer: An Australian Study." Palliative Medicine 22(1):59-69. doi: http://dx.doi. org/10.1177/0269216307084608.

Mulyana, D., \& Verity, F. (2016). "Health Consumer Participation, Medical Dominance and Digital Ethics in Indonesia: The Prita Case." Health Sociology Review 25(3):300-311.doi: http://dx.doi.org/10. 1080/14461242.2015.1116021.

Mulyana, D. (2016). Health and Therapeutic Communication: An Intercultural Perspective. Bandung: Rosda.
Rahmawati, D. (2017). Communication as the Key of the Life Navigation of Online Game Players: An Ethnographic Study of the Online Game Players Life in Jabodetabek Cafes. Unpublished Doctoral Dissertation Padjadjaran University.

Robinson, W. D., Carroll, J. S., \& Watson, W. L. (2005). "Shared Experience Building around the Family Crucible of Cancer." Families, Systems, \& Health 23(2), 131-147. Retrieved from http:// search.proquest.com/docview/61443997 5 ?accountid $=17242$

Skalla, K.A., M.Bakitas, C.T.Furstenberg, T. Ahles,J.V.Henderson. (2004). "Patients' Need for Information about Cancer Therapy." OncologyNursing Forum 31(2):313-319.

Yusuf, U \& Setianto, R.L.(2013) "Efektivitas 'Cognitive Behavior Therapy' terhadap Penurunan Derajat Stres." Mimbar 29 (2): 175-186. 